\title{
1. The idea and creation of an international court
}

\section{INTRODUCTORY REMARKS}

The idea of some form of international justice, and the efforts to achieve it, have been around for a long time. From the Middle Ages until the nineteenth century it featured prominently in a series of purely theoretical plans for a European, or even a world, federation. Pierre Dubois, King George Podiebrad and Anton Marini, Emeric Crucé, Sully, William Penn, Abbé St Pierre, Jeremy Bentham and Immanuel Kant, among others, anticipated such a federation ${ }^{1}$ in which a judicial branch (or system of arbitration) should settle disputes having a legal nature or complexion. The basic idea behind these more or less articulated schemes was always to reduce international anarchy and to achieve, in international affairs as in the domestic arena, the great leap from a 'natural society' to a 'civil society'. If the main evil of international society, especially as it emerged after the Westphalian peace, is rooted in the excessive presumption of sovereignty, the solution must be to limit the reach of sovereignty by the device of a federal power that embraces the whole 'civilized' (as it was thought of at the time) world. By entering into such a federation states would relinquish these excessive sovereignties (who were constantly in conflict with one another) in favour of a centralized power. Not only would rivalry between sovereignties be eliminated - as there would remain only one sovereign subject with no possible competition from outside - but moreover international society would be transformed into one in which the rule of law prevails. The leap would be from politics to law. Indeed, the federal power is organized in such a way as to ensure the application of federal laws to which all entities contribute; tribunals would sit to ensure that the law is correctly applied. In essence, these visions are all built on the conception that international society must undergo the same gradual transformation as the traditional internal forces that merged into the modern state.

1 See E. York, Leagues of Nations, Ancient, Medieval, and Modern (London, 1919); L. Ledermann, Les précurseurs de l'Organisation internationale (Neuchâtel, 1945). 


\section{The Elgar companion to the International Court of Justice}

In view of the political reality, however, that power was split into a series of sovereign states, it is clear why these projects could not hope to have more than little success. They were the personal visions of enlightened people with no roots in political reality. The fact remains today that when a nation has been granted sovereignty in its rise as an independent state, it will not readily relinquish that supreme power on the basis of 'less anarchy' or 'better order' arguments, which appear remote and abstract to the great majority of persons, whereas loss of autonomy and power is perceived as concrete and undesirable. However, the idea of a world federation was never completely lost: its supporters would realize it in a different and more limited way than that initially envisaged, and it would thus find some degree of application.

\section{THE SHIFT IN THE HISTORICAL LANDSCAPE}

The nineteenth century witnessed significant events which would gradually change the course of practical and political perceptions and open the way to innovation in international society. The first of these is industrialization, which paved the way for ever-increasing interdependencies at the economical, commercial and financial levels. For as long as exchanges were mainly localized, economic factors would not be in opposition to the presumptions of sovereignty. Industrialization, the revolution in transport (trains and shipping, for example), the emergence of an economic foreign policy, colonization, and other related factors gave way to a new picture and to new realities. Second, the raw materials necessary for this industrial growth were mainly situated overseas. This was one of the main reasons for colonialism. It introduced international gambling and friction in the run on those territories, and also increased - to an extent not readily understood - the interdependence of the modern world. The world in the wake of the First World War was in a sense at least as globalized as it is today, a fact which is often forgotten.

Third, and importantly, the function of war began to shift. Up to this point it had been a fairly limited device for the settlement of a dispute. Professional armies of some king would be cast on a battlefield to obtain some territorial advantage at the expense of another king - all carried out without dragging the civilian population into the hostilities and without creating national ill-feeling among the population. War was thus limited. It concerned the raison d'Etat, the policy of aggrandizement of kings. In the nineteenth century, war became an altogether wholly different phenomenon, both in its destructive reach and in its perception. In the first place, it became a matter for the whole nation, a matter of national 
interest. General conscription, starting with the Napoleonic wars, brought into being huge armies who were not as well-trained in warfare as the former professional soldiers. National propaganda turned the issues at stake into questions of national passion and mutual hatred among the peoples, as illustrated by the German-French wars. Momentous advances in technology developed weaponry to an unprecedented extent. Chemical weapons, missiles, aerial bombardment and nuclear capability have given war a completely new personality: it became total war, wreaking immense havoc and resulting in unprecedented destruction.

Confronted with these new realities - growing interdependence on one side, the destructiveness of war on the other (war being the essential attribute of sovereignty: the right of a sovereign state to proceed to war, jus ad bellum) - political forces looked for novel solutions, which could not lie in traditional sovereignty. They had to look ahead and try to 'organize' international society in order to better control and police the centrifugal forces. Contrary to the earlier visions of an international federation - which were little more than stimulating intellectual exercises by ethically enlightened individuals - the efforts of the nineteenth century had an altogether practical reach; hence the blossoming of peace societies, learned societies on the development of international law (such as the Institut de Droit International and the American International Law Society), programmes of political parties (generally on what was considered the so-called progressive spectrum at the time), and so on. They would change the perception of international relations.

\section{THE NEED TO STRENGTHEN INTERNATIONAL LAW}

Out of these efforts a three-pronged effort for progress quickly emerged. It was encapsulated in the triptych 'security - disarmament - arbitration', an approach that still prevailed at the time of the League of Nations.

Security: This was aimed at limiting the jus ad bellum (right to war) of states by laws and institutions geared toward the maintenance of international peace, coupled with international police action by a federal organ against potential or actual aggressors. Maintaining the peace implied the existence of an international organization of a political nature, which gave rise to the League of Nations and later the United Nations.

Disarmament: It is difficult to keep the peace when states are constantly increasing their armament capacity, which in turn pushes other states to arm themselves more heavily. Increased armament creates a 


\section{The Elgar companion to the International Court of Justice}

feeling of insecurity and gives the impression that a state is preparing for war. Moreover, resources necessary for other purposes are then lost in procuring armaments. With the progressive realization of 'security' through the international organization, states would be willing to arm less heavily as they could count on help from this organization against foreign aggression. It would therefore be possible to negotiate for reductions in armaments within that organization; this would be a progressive endeavour.

Arbitration: It is not enough simply to disarm and suppress the unilateral use of force (except by way of temporary self-defence) as states will continue to have disputes among themselves. If nothing is done to resolve these disputes, they will progressively become more serious. If a state feels that it is unable to enforce its rights as it is prohibited from using force, it may be faced with having its legal rights violated by other states; it will finally lose patience and could be tempted to resort to force. In order to be complete, therefore, a scheme for progress must include the proper channelling of disputes towards a system of dispute resolution; there must be some type of body able to hear and to adjudicate on such disputes. This is arbitration. For as long as no such international institution existed, arbitration had to assume the burden for the resolution of all disputes which could not be settled by negotiation, those which were political in nature and those which were essentially of a legal nature.

With the advent of the League of Nations, a further refinement was proposed. Disputes which were essentially of a political nature (the dispute is not about a legal right but about how to create a new norm of law or how to accommodate interests) could be brought before the League Council; disputes which were of a legal nature (the dispute revolves around the interpretation and/or application of a legal norm) could be brought to arbitration or to an international tribunal. However, it was not sufficient to say that an arbitrator should decide all disputes or only those which are essentially of a legal nature, as that arbitrator must be able to rely on a body of rules on the basis of which he is able to decide the dispute. This is most obvious in the realm of 'legal' disputes. If international law is undeveloped or non-existent, the arbitrator is not able to reach a decision on the dispute on the basis of predictable rules. The parties are left in the undesirable situation either of their dispute remaining unresolved or accepting a discretionary decision. The spectre of self-help would thus not be eliminated. Hence, an important aspect of the programme was the development and codification of international law. 
International law should first be developed: it still contained too many gaps, it was uncertain and shrouded in incomprehensible diplomatic precedents. International law had to be codified; only then could it be made accessible and clear so that it could guide the actions of governments and provide a basis for arbitral decisions. It may be argued that this approach was optimistic, somewhat mechanical and rather simplistic, but it was the way in which things were approached at that time.

\section{THE MOVE TOWARDS AN INTERNATIONAL COURT}

At the global level, the creation of an 'international court of justice' underwent three stages:

- the organization of a comprehensive scheme of arbitral justice;

- the attempt to create a permanent and compulsory 'arbitral court';

- the creation of an institutional court, linked to the League of Nations - the Permanent Court of International Justice (PCIJ).

Throughout the nineteenth century, there had been a significant return towards arbitral practice. Many states had decided to resolve disputes between or among themselves by recourse to a nominated arbitrator or to a college of nominated arbitrators. Important decisions had been given in this way, such as the Alabama arbitration of 1872 between the United States (US) and the United Kingdom (UK). The first step would therefore be the attempt to consolidate this practice, and to offer states a basis for having more simple recourse to arbitration for settling their disputes.

The second step would be to establish a compulsory scheme for arbitration in a particular area of international law that was particularly appropriate for such a course. The idea of a permanent arbitration tribunal emerged in this context as the compulsory character of jurisdiction implies the existence of a tribunal to which each state could turn in order to have its claims decided.

The third step would be to create an institutional tribunal of a permanent nature, linked to an international organization. The arbitrator is the common organ of the parties in dispute; he is subject to the wishes of the parties and has to bow to their common will. Hence, the handling of the case and the procedure are still essentially in the hands of the parties. An institutional tribunal is independent from the parties in dispute. It is created by a community of states (for example, states parties to the Statute of the PCIJ) and delivers justice in their name. It is based 
on a set of rules adopted in advance and on the basis of which it will function. The parties to a dispute must accept these rules; they can influence them only to the extent that these rules give some place to their common or unilateral will. Such a tribunal represents more the 'international community' than the single and occasional states in dispute.

Moreover, an institutional tribunal is permanent: it does not dissolve after having heard a case of a series of cases. It remains in existence in order to be accessed by states at any time, to settle a dispute of greater or lesser urgency, and it is in a position to develop a jurisprudence. Such a tribunal thus more closely resembles the tribunals of municipal law than does an arbitral tribunal. Let us now examine each of these steps in more detail.

\section{FIRST STAGE: CONSOLIDATING PRACTICE}

During the first stage an attempt was made to provide some general regulation for arbitration in order to facilitate its use for those states willing to resort to it. This was one of the objects of the Hague Peace Conference of 1899, and the follow-up conference of 1907. In the area under consideration, the aim of the 1899 Conference was to create the framework for optional arbitration. It did so by providing a set of rules that provided for the immediate operation of arbitration only if the states in dispute so wished. In this way, the so-called Permanent Court of Arbitration (PCA) was created. It was not permanent in the sense of a standing tribunal, always accessible; it operated through a permanent Secretariat (Bureau) where states could select arbitrators from a list and thus constitute a tribunal when they wished to do so. This arbitral tribunal was distinct from the PCA itself; it was an organ of the parties constituting it, not an organ of the PCA.

Moreover, the PCA had its own rules of procedure; thus the states in dispute were not required to agree to these rules in each case in order to allow the operation of the particular tribunal. Indeed, arbitrators could resort to the model rules inserted in the Hague Convention I of 1899 (and 1907) in relation to the peaceful settlement of disputes. Clearly, the parties could agree on other procedural rules for 'their' arbitral tribunal. The model rules of procedure were in that respect subsidiary to any rules directly agreed between the parties. However, if the parties had not agreed on different rules, the rules set out in Convention I would apply. This eased access to and the operation of arbitral justice significantly. It is in this sense that article 20 of the Hague Convention I of 1899 (and article 41 of the 1907 convention), in the opening section on the PCA, 
must be read: 'With the object of facilitating an immediate recourse to arbitration for international differences ...' The word 'immediate' conveys the idea that no time need be lost (time which may be crucial for a successful settlement or even the maintenance of peace) in constituting the tribunal; the Convention contains all that is necessary to ease the process.

However, the Court is little more than a 'phantom' or virtual institution: it is composed of administrative organs and a list of arbitrators, and nothing more than that. As in all societies in the early stages of their institutional development, the resolution of disputes starts out with a free-rein optional arbitration scheme, resting essentially under the control of the wishes and wills of the parties in dispute.

\section{SECOND STAGE: PROPOSALS FOR COMPULSORY DISPUTE SETTLEMENT}

Some years later, it had become apparent that the progress made in 1899 was insufficient. Therefore, at the 1907 conference many of the smaller states (and some of the larger states) proposed the establishment of a permanent court vested with compulsory jurisdiction in certain subject areas. The proposal put forward by the US was particularly bold: the creation of a new permanent court alongside the old PCA. This new court would be a standing entity, supported financially by all states parties to the new convention, thus ensuring representation of the various legal systems; it would be composed of professional and non-removable judges and would hold regular sessions. The US had drawn on its own experience in proposing this reform: in 1777 it had started with a court of arbitration before establishing, ten years later, its Supreme Court, which is still in operation today. It could be said, therefore, that the PCIJ, to be created some 13 years later, was originally based on a US proposal.

However, the proposal was defeated in 1907. The main reason was the impossibility to reach a consensus on the composition of the Court. Clearly a judicial body could not represent, through its judges, all the states parties to the convention instituting it; that would have resulted in an excessive number of judges. Once it was admitted that the Court should have a restricted representation, the question of how to distribute the seats became acute. The smaller states feared being marginalized by a court dominated by the greater powers, which would fly in the face of the bedrock principle of international law of the time - the strict and formal equality of states. Brazil was particularly attached to the idea of equality and proposed having one judge nominated by each state, which would 
have brought their numbers to 44 . In addition, some states were opposed to the principle of compulsory, as opposed to optional, jurisdiction. At the conclusion of the debates, it was possible to do no more than to annex the new arbitral court project to a resolution expressing a recommendation to the states.

However, the US remained active in trying to achieve progress. There was hope that a breakthrough could have been reached in the third revision conference, scheduled for 1914, but because of the outbreak of the First World War this conference was postponed. After the war, however, the tide had turned. It was no longer the time to continue the efforts of the Hague Conferences: a new approach was adopted through the creation of a world organization - the League of Nations.

\section{FAILED ATTEMPTS TO CREATE AN INTERNATIONAL PRIZE COURT}

At the 1907 conference, an abortive attempt was made to establish a standing international tribunal with limited ratione materiae jurisdiction, constructed on the arbitral model. The proposal was to establish an international court for maritime prizes during wartime - a project that responded more to practical needs than a political effort to 'organize' international society in order to maintain peace and reduce anarchy. Indeed, a maritime prize implies that two or more states are at war: peace has already been breached. In sum, the efforts under this limb were less political and more technical.

In accordance with the applicable rules of maritime warfare, a tribunal must adjudicate on any prize. A prize would typically be a commercial ship having infringed the rules relating to contraband or blockade or, less typically, a hospital ship having violated its duty not to take part in hostilities. Such ships, or in some cases simply their cargo, could be seized by a warship on the side of the adverse belligerent and appropriated. This action, however, was subject to judicial review, which was thought to counterbalance to some extent the harshness of the rule whereby a ship or cargo could be appropriated by the captor. Such a judicial guarantee was especially important for ships of neutral states. While the national prize courts of the capturing state were independent, there remained the fact that they were not perceived as being independent (and sometimes, in fact, were not) in that they 'belonged' to the capturing state - a state at war. These national tribunals thus seemed to be based on the principle that the state was judge in its own cause. 
To overcome this apparent bias, there had been proposals, since the end of the eighteenth century, to establish mixed arbitral tribunals. One such proposal was for national prize courts to adjudicate at first instance, with a right of appeal to the mixed arbitral tribunal. The time was ripe to realize this project in 1907. Sponsored by the US, the UK, Germany and France, Convention XII was adopted, which established an international prize court (IPC). The system of a national judgment and an appeal to the IPC was approved in articles 2 and 3 of Convention XII. Where there was no national prize court, the international court could be accessed directly.

However, two points proved to be particularly problematic and finally doomed the IPC to failure. The first problem was the law to be applied. Article 7 of the Convention provided that the Court should first apply any treaty in force between the parties to the dispute; in the absence of a treaty, the rules of international law (which meant customary international law) should be applied and, failing the existence of such rules, 'in accordance with the general principles of justice and equity' (\$2) - a forerunner of article 38, 3 , of the Statute of the PCIJ and article 38, $\S 1$ (c) of the Statute of the ICJ. Since treaties were not always applicable and customary law not always certain (or, indeed, in existence) some states feared that the Court would engage in creating new law under the umbrella of 'principles of justice'. Instead of applying the traditional rule that a prize must be allowed if it is not contrary to existing legal rules under international law, the Court could condemn a prize under further principles, which were not entirely foreseeable. Thus, the UK, being most interested in this subject, attached importance to developing prize law before establishing the Court. The Court would then have firm legal rules to be applied and would engage less often in considerations of equity. The UK convened a Conference in 1908 to try to achieve this result but consensus proved to be impossible, especially on the question of contraband.

The second major difficulty was the composition of the Court and the principle of equality. According to article 15 of the Convention, the judges nominated by the eight great powers (Germany, US, AustriaHungary, France, UK, Italy, Japan and Russia) were to sit permanently $(\S 1)$; the other judges would rotate according to a scheme annexed to the Convention $(\S 2)$. This rule of open inequality was objected to by many smaller states (Chile, Cuba, Ecuador, Guatemala, Haiti, Persia, El Salvador, Siam, Turkey and Uruguay), which entered reservations to article 15. At that time, a reservation had to be accepted by all other contracting parties in order for it to have effect; in the absence of acceptance, the reserving state would not become a party to the convention. It is 
understandable, therefore, that because of these two obstacles the Convention was not ratified and did not enter into force.

All of these unproductive attempts to establish a permanent and standing court had at least cast light on the advantages of such an institution. First, a standing tribunal can most easily be seized to hear a case; valuable time is not wasted in trying to establish it. Moreover, such a standing tribunal can be seized unilaterally by a state, especially when consent to its jurisdiction has already been provided for in a convention or other instrument. By the same token, the defendant state cannot successfully try to blockade the process of establishing the court, by refusing to appoint its arbitrators contrary to a previously assumed obligation. What is more, the tribunal can easily dispose of any objections to jurisdiction or admissibility. The principle that a judicial body is judge of its own jurisdiction (la compétence de la compétence) could thus gain ground. It would strengthen the growing arm of international justice. Also, the tribunal's procedure can be organized in advance and set out in rules of court. This achieves a form of professionalism and rationalization.

The second advantage is that a standing tribunal can add to the palette of available means to settle disputes. Arbitration by certain appointed lawyers, diplomats or experts can be appropriate for technical matters or, conversely, can also be useful for political disputes, where the legal element does not predominate and where the main point is to reach a compromise. An international institutional court can add a body to judge strictly in accordance with legal sources and gain authority in that area. The states will benefit from this 'double offer', since they remain entitled to choose freely the means through which they prefer to channel their dispute.

Third, a standing institutional court will contribute to the development of international law and to the establishment of a jurisprudence. Arbitral tribunals are normally set up ad hoc for a single case; the aim of the parties is to settle their dispute and only this dispute; they will often impose special rules to be considered by the arbitrators. The arbitrators will not necessarily be aware of precedents of other tribunals, nor will they need to be greatly concerned with them. Their function is the proper settlement of the particular case before them. Deprived of institutional memory, their contribution to the development, ascertainment and crystallization of international law tends to be minor. By contrast, an institutional tribunal will often feel and behave not so much as a 'mandatory of the parties', but as a body judging in the name of an international community and indebted to international law itself. This is particularly visible in the PCIJ and ICJ. The advantages of arbitration lie 
in the realm of flexibility and adaptability to the wishes of the parties. Those of institutional justice lie in the application of objective international law. Both devices taken together cover a broader spectrum and give the states greater choice as to the way in which they prefer to settle their disputes. Their choice will depend largely on how they perceive the dispute.

On the other hand, there were apprehensions, doubts and fears in relation to the establishment of an international court. First, it was emphasized that international law was still a very uncertain body of law, not codified, emerging from shifting practices, with many gaps. If a court of justice were to apply such a body of law, would it not in practice be as acting like a 'government' of judges, more often than not creating an appropriate rule of international law rather than simply applying one?

Second, the still all-pervading conception of the sovereignty of the state could cast doubts on the functions of an international court. True, if a purely consensual jurisdiction was upheld, the sovereignty of the state could be fundamentally protected. But there remained questions such as the provisional measures by the Court, which could impinge significantly on the sovereign freedom of states accepting its jurisdiction; hence the vague formula in article 41 of the Statute of the PCI, on provisional measures, where it is stated that the Court may 'indicate' such measures. Nothing is specified on their binding character. Third, at the time it was still doubted that it would be feasible to distinguish properly between 'legal' and 'political' disputes; or conversely whether it was wise to distinguish neatly between these two types of dispute, assigning one to political organs and the other to the court of justice to be created.

\section{THE THIRD STAGE: A PERMANENT COURT}

The third stage - based on the creation of a true institutional court and not simply a type of permanent court of arbitration - was reached after the First World War, with the setting up of the Permanent Court of International Justice (PCIJ). The word 'permanent' - which could give rise to some misplaced derision in that it was dissolved in 1946 - was not intended to connote the idea of eternity, but to emphasize the fact that the court is a standing entity, always operational and accessible, and composed of professional judges. In this sense the Court has indeed been permanent, even during the war years when it did not function judicially; its President remained in constant contact with the organs of the League of Nations and a Dutch professor of international law remained in the Peace Palace to guard the Court premises. 
The time was indeed ripe, after the First World War, for the creation of a permanent tribunal. The destruction caused by the war had opened the way for bolder intrusions into sovereignty and equality, the former stumbling blocks of successful innovation. The establishment of the League of Nations produced a form of world governance. It was obvious that this body should have the same essential features of public organization as any public body, with a political executive organ, a 'democratic' assembly and a court of justice. Thus, article 14 of the League of Nations Covenant entrusted to the League Council the task of preparing a draft proposal for a 'Permanent Court of International Justice' (the Italian draft had already proposed the name 'International Court of Justice') and then to submit that draft to the Members of the League.

In 1920 the League Council turned the project over to a committee of ten respected jurists of equal geographical spread. It was on the basis of their report that the Council could examine the final text and submit it to the Assembly (through which all members were represented) for adoption. With regard to the wording of article 14 of the Covenant, however, it was doubtful that the Assembly itself was competent to adopt the Statute of the Court. It was thus decided to first approve the Statute in the Assembly, thus giving it formal status, and then to submit it for separate adoption/ratification by member states through a Protocol of signature (of 16 December 1920). In 1921, the required simple majority of member states of the League ratified the Protocol, enabling the Second Assembly to proceed with the election of judges. The Court held its inaugural session on 15 February 1922 in which it elaborated its Rules of Court, which were adopted on 24 March 1922. Thus, the first 'World Court' came into existence.

The PCIJ was a remarkably successful institution. It delivered 32 judgments on jurisdiction/admissibility and merits, all of which were implemented (although not always without difficulty), and 27 advisory opinions, most of which were acted upon. ${ }^{2}$ Furthermore, it adopted 137 orders relating to procedure in particular cases. A total of 66 cases were brought before the Court. Twelve cases were withdrawn after having been started - the last two in 1945 after the war. ${ }^{3}$ We will see later the types of case in which the Court exercised its jurisdiction. Suffice it to say at this juncture, it dealt with many cases arising out of the peace settlement of 1919-23 on the basis of treaties and conventions; it also

2 See M.O. Hudson, The Permanent Court of International Justice, 19201924: A Treatise (New York, 1943), pp. 513ff.

3 See the Sixteenth Report of the Permanent Court, Ser. E/16, pp. $92 \mathrm{ff}$. 
heard cases that hinged on general international law, as shown, for example, by the famous Lotus case of 1927. The Court's cautious and conservative stance in contentious cases, along with its bolder and more progressive jurisprudence in advisory cases that dealt with the powers of nascent international institutions (reinforced by the Court's contribution), proved to contain the right mix of judicial caution and judicial activism; thus the Court was largely accepted immediately by both states and international institutions. It enjoyed great prestige throughout the $1920 \mathrm{~s}$ and 1930s, and the disillusionment into which the League of Nations fell never affected it, notwithstanding its close institutional links with 'Geneva'.

The main achievements of the PCIJ can be summarized in the following six points:

1. The Court set the ground for a permanent international tribunal. If the potential and success of such a tribunal could be doubted - and, indeed, it was doubted - before the PCIJ was established, such doubts could no longer be sustained in 1945. It is therefore natural that the ICJ should be created to succeed the PCIJ; the only question was how to strengthen its role and facilitate its work.

2. The Court contributed greatly to the material development of international law. Contrary to the position today, in 1919 there were many gaps in international law. There were at the time hardly any codified conventions on important issues such as the law of treaties, the law of state responsibility, the law of the sea and the law of diplomatic relations. The very concept of customary law was still underdeveloped, as prevailing positivism tended to construct it as based on 'tacit agreement', thus linking it heavily with the law of treaties. In many areas, such as the law of responsibility, pronouncements by the PCIJ have 'classical' status today and express the applicable law - consider, for instance, some of the dicta on reparations in the Chorzów Factory case. ${ }^{4}$

3. The PCIJ rooted in the legal consciousness the concepts of international case law and jurisprudence, not only in developing the law but also in clarifying and gradually crystallizing it. The pronouncements of the Court were no longer to be considered as simple statements for the resolution of a particular conflict, but as decisions carefully crafted in order to contribute to a progressive

4 PCIJ, Ser. A, No. 17, 1928, p. 47. See generally H. Lauterpacht, The Development of International Law by the International Court (London, 1958). 
clarification and evolution of the law. Hence, attention was focused more on motive and reasoning than simply on the operative part of the dispute, as had been the case under the former system of arbitration (where motive was sometimes not considered at all). This attention to the 'jurisprudential' side of the Court's approach contributed to a greater visibility and transparency of the law. Several digests of the Court's practice contributed to make that jurisprudence readily accessible and readable, and its case law was now being studied academically.

4. A procedural law for international tribunals was gradually established. The Rules of Court of 1922 and 1936, as well as the case law of the PCIJ, shaped the body of law which until then had featured only in the Hague Convention I of 1899/1907 in the form in which it was necessary and useful for arbitration. The concept of 'preliminary objections' was developed - a concept still in its infancy in the 1920s but which gained great momentum in the 1930s. The PCIJ also contributed to the creation of a law on provisional measures, especially as regards the criteria of urgency and irreparable harm. The same could be said for issues of intervention by third states or counterclaims, although these areas benefited from further clarification by the ICJ. It is no accident that today many international tribunals (for example, in the field of investment law) still refer to the jurisprudence of the ICJ on procedural issues.

5. The PCIJ did much to cement the idea that some form of rule of law could be applied among states and, in particular, states in dispute. The idea that relations among states need not be confined to the political side of reality, and that there is also a legal side which can be used as a tool of conflict resolution, was not new; it had still to be rediscovered after the disaster of the First World War.

6. The Court did much to foster a great degree of confidence and prestige in its function, although there were some later notable eclipses (especially in the late 1960s and 1970s), the effects of which have lasted to the present day. The quality of its work and the attentiveness of its approach have often been lauded. Thus, it has been said that:

Les décisions rendues jusqu'ici ont mérité, à juste titre, l'approbation générale. Basées sur une solide argumentation de fait et de droit, rédigées dans une forme claire et sereine qui force la conviction, elles apparaissent bien comme des œuvres d'une absolue impartialité et 
justifient pleinement l'espoir et la confiance placés en la haute juridiction dont elles émanent. ${ }^{5}$

Or, in other words:

The experience of the Permanent Court, its dispassionate and unhurried consideration of the issues brought before it, the high standards of personal integrity, professional competence, and worldly wisdom, of its Members, the fact that the judicial pronouncements were endowed with strong moral authority in addition to their formal finality and the accumulation of experience in the Registry - all these constituted an intangible asset on the positive side of the balance-sheet. ${ }^{6}$

There have been no scandals attached to the Court, or major problems (apart from minor organizational issues when some judges could not easily reach The Hague because of the long distance from their home countries; on occasions this put into jeopardy the required quorum to constitute the Court in a given case). The only regretful event was the deterioration of international relations in the 1930s and the advent of the Second World War; although this was hardly something that could be attributed to the Court, it nevertheless involved its societal and political surroundings.

\section{NOTES, COMMENTS AND EXTRACTS}

It was suggested earlier that, following the First World War, the general climate was favourable for the creation of a permanent tribunal - 'the destructiveness of war had opened the way for bolder intrusions into sovereignty'. However, as with earlier attempts to establish an international court, there were factors that could also have prevented the success of this new project. These factors, which remained unchanged in the newly generated political environment, had already doomed to failure, in 1907, the US proposal of a permanent court with compulsory jurisdiction and the IPC. They were:

5 N. Politis, La justice internationale (Paris, 1924), p. 191 ('The decisions rendered until now have deserved the general approval they have elicited. Based on a solid argument of fact and law, written in a clear and serene style commanding adhesion, these decisions reflect absolute impartiality and justify the hope and confidence placed in the High Court from where they emanate').

6 S. Rosenne, The World Court, What it is and How it Works (5th edn, Dordrecht/Boston/London, 1995), p. 19. 
- the underdeveloped state of positive international law, with too many lacunae for it to provide the basis of predictable judicial decisions (or, indeed, of any decision at all) in every case; and

- the importance still attached by most states to formal equality, manifested in their fear of having a court dominated by only a handful of states.

So, without underestimating the readiness of the international community to prevent another war, how did the establishment of a permanent court of law succeed in the 1920s? How did it overcome the fears that (i) in the absence of conventional or customary rules of international law the Court would engage in lawmaking, and (ii) given that a limited number of judges could constitute the bench, the judicial body would not be fairly representative?

Set out below are extracts of the arguments and opinions on these two issues advanced by Mr Raul Fernandes, one of the ten members of the Advisory Committee responsible for drafting the PCIJ Statute. The first, a statement of the applicable law, reflects the compromise reached between the Committee's members who wanted the new court, at any cost, to avoid pronouncing a non liquet, and the members who favoured a court that would decline to hear a case if international law had no clear rule that applied to the case. The second, an extract from the procès verbaux, features Mr Fernandes' explanation of how the process of electing judges for the new court, partially dependent upon the League Council, could satisfactorily respond to the needs of equality and fair representation of those states not represented in the League Council.

\section{Extract $1^{7}$ \\ Statement of Mr Raul Fernandes}

It seems to me essential to find at any cost a basis for conciliating the views expressed on the one hand by the President and on the other by Mr Root. The question merits the effort because the whole future of the Court depends upon it. For very good reasons Mr Root opposes granting to the judges - in addition to their ordinary task of applying international law the power to some extent to create it. He believes that a great

7 Advisory Committee of Jurists, Procès-verbaux of the Proceedings of the Committee, 16 June-24 July 1920, with Annexes (1920), pp. 345-6. 
Power could never agree to a system, which would lay it open to having its disputes settled by the application of a rule which had not been approved by it; or, what will be more serious, of a rule whose legality it had systematically contested at all times. I think that Mr Root might say the same thing of any state whatever, and perhaps with even more reason of those not provided with military power. But, on the other hand, all that is true and wise in the President's proposal must be recognised, especially if one considers it in the light of the eloquent and noble speech which he addressed to the Committee yesterday. For it is obvious that if the judges are strictly confined, apart from law derived from Conventions and Treaties, to the use of international custom (and such is Mr Root's idea) the possibility of administering justice in many cases which involve legal relations between the states concerned, and from that fact clearly capable of legal decision, is taken away from them. I include disputes which, though not regulated by usage - either because there is no precedent or perhaps the precedents are not numerous or consecutive enough to establish custom - nevertheless are founded on certain incontrovertible principles of law. The many sides of daily life which constantly present cases unprovided for by legislation, often bring such cases before National Courts; and I should not exaggerate if I said, that more often than not, the judge cannot find a rule intended to deal with the question, and finds it necessary to pass sentence on a rule derived from the general principles which guide and give life to national law. Nor should I exaggerate if I said that the sentences thus passed were generally the more just; because the principles are always based on justice, while strict law often departs from it. What does this amount to? Has the judge under these circumstances acted as a legislator and created a juridical rule? Not at all, he has merely brought to light a latent rule, as Ihering has put it. Such a rule is quite legitimate because it is logically contained in a principle already recognised by the Nation concerned. What is true and legitimate in national affairs, for reasons founded in logic and not in the arbitrary exercise of sovereignty, cannot be false and illegal in international affairs, where, moreover, legislation is lacking and customary law is being formed very slowly, so that the practical necessity of recognising the application of such principles is much greater. It is quite superfluous to give examples of rules not established either by convention or custom, which nevertheless must inevitably be accepted in the minds of 
the Nations, because of the principles on which they are based. I desire, nevertheless, to mention one which is particularly striking because it illustrates this theory both ad rem and ad hominem: it is that of the 'American Declaration of Rights and Duties of Nations' and especially the commentaries on this declaration, a work due, if I am not mistaken, to the very able lawyer Mr James Brown Scott, who is present. I think that the project would give satisfaction to both the opposing theses in giving to the Court of Justice the power to base its sentences in the absence of any conventional or customary law - on those principles of international law which, before the dispute, were not rejected by the legal traditions of one of the states concerned in the dispute. It seems to me that this formula would remove $\mathrm{Mr}$ Root's objection and at the same time would prevent the Court from becoming in many cases a 'registry for the high-handed acts of the strong against the weak', as M. de Lapradelle has said so expressively and well.

\section{Extract $2^{8}$}

M. Fernandes thought that he should present Brazil's point of view which in his opinion was the same as Latin America's in general. First of all, he would examine the proposed systems. MM. Adatci and Ricci-Busatti provided for the direct representation on the Court of Justice of the states which are permanent members of the Council of the League of Nations, reserving to the other states an indirect representation by means of the election of a certain number of judges by the Assembly of the League. M. Fernandes was astonished to hear M. Adatci advocate this system and say that consideration must be had for undeniable realities, namely that a Court on which the said Powers were not represented would necessarily be impracticable. Certainly it is desirable that the plan submitted for the organisation of the Court should give to the states in question a complete guarantee concerning the impartiality, the independence, and the ability of the judges; not because they are the

8 Ibid., pp. 365-8. 
great Powers, according to the regrettable terminology introduced in diplomatic language, but because in a given case their responsibility and their interests are more deeply affected, since it would be necessary in order to enforce the execution of a sentence that they take coercive measures of a military and economic character.

However, in order that the Court be practicable, it should satisfy all the conditions of success. MM. Adatci and RicciBusatti thought that they would fulfil one of these conditions by sacrificing without consideration the principle of legal equality of sovereign states; but they would arrive at the diametrically opposite result, because it should be kept firmly in mind that the majority of Members of the League of Nations are immutably opposed to any rule involving disregard for this principle. If the Great Powers desire a Court which shall judge only their disputes they are on the good road. But if, on the contrary, they desire a Court whose competence covers a number of states equal to that which forms the League of Nations, it would then be necessary for them to adjust their legitimate interests with the frank application of the principle of equality of all sovereign states.

M. Fernandes himself had no vote to cast; he felt no hesitation in stating this since he had not taken his seat until the Secretariat-General of the League of Nations had explained to the Committee that this right to vote was dependent on his eminent fellow-countryman, M. Bevilaqua. However, in order that the Committee might not be in doubt for an instant, he wished to say that if, which he did not think possible, the proposals which he objected to were accepted by the Committee, Brazil, in agreement with the majority of states interested, when the time came, would, without fail, vote against the project, thus causing the fall of the institution which the whole world wished to see powerful and lasting.

M. Fernandes then turned to the President's plan. This plan aims to satisfy both the large states represented on the Council of the League of Nations and the bulk of states represented on the Assembly by making the Council and the Assembly cooperate in the election, the Council preparing the list of candidates from which the Assembly shall make its choice. But it must not be forgotten that concurrent with the list prepared by the Council another list drawn up by the Hague Court of Arbitration shall be presented to the Assembly. 
Therefore in fact the Assembly shall remain free to disregard the list presented by the Council and limit its choice to that of the Court of Arbitration; the Council would thus find itself isolated from any participation in the election. It is obvious that the guarantee given to the Great Powers would be deceptive and under these circumstances $M$. Fernandes thought that the project would have no chance whatever of being accepted. Could it be amended in suppressing the list to be prepared by the Court? That probably would remove the opposition of the Great states, permanent members of the Council, but would excite the opposition of the states who made up the Assembly. The latter in practice would no longer find themselves in a position to exercise their choice or carry out an election under satisfactory conditions of freedom, since their part would be limited simply to a statement of preference for 15 candidates among the 30 nominated by the Council.

M. Fernandes was of the opinion that the Root-Phillimore project succeeded better in the very delicate task of conciliating all the interests concerned. By making the choice of judges dependent on the concurrent vote of the majority of members both of the Council and of the Assembly of the League of Nations, this plan gives to the two organs of the League an equal participation in the composition of the Court. The creation of a small Court is anticipated, a condition sine qua non of its authority and its real permanence. This implies necessarily that many states will not be able to have their subjects among those elected; but by this very fact the representation of states is wisely avoided, the judges being elected regardless of their nationality, which is taken into account only when it is a question of preventing one state having more than one of its subjects on the Court.

Thus in the largest degree possible the representation of the various legal systems and the principal forms of civilisation is assured. This plan at the same time makes allowance for the susceptibilities which in the past have brought about the failure of a tribunal on which certain states were represented by judges which they named to sit upon it, while other states remained practically outside.

M. Fernandes thought that the Root-Phillimore plan took the necessary step for the advent of international justice by breaking with the prejudice of having the states as Powers openly represented on the Court. That was his fundamental idea, and 
M. Fernandes was pleased to state that he was in that respect in agreement with the plan sent by his distinguished fellowcountryman, Professor Bevilaqua.

It is very probable that the Great Powers will have their subjects among the 15 judges elected. It might even be said that it is certain, because the authority of the Court's sentences, in so far as their practical execution was concerned, would depend on these states; and the other states which are unjustly underrated have enough political sense to take this into consideration. But it remains, nevertheless, that the machinery of the plan does not exclude in advance the subjects of any states, just as it does not provide at the outset for the entrance of a subject of any Great Power into the Court. For the first time, by this means, the principle of legal equality of sovereign states is completely applied.

Unfortunately a shadow is cast over this beautiful picture: the project gives a double vote to states represented both in the Council and in the Assembly in an election in which those who are represented only in the Assembly have but one vote. A flagrant wrong here is done to the principle of equality; it is impossible to hide the fact.

Even should there be any desire to conceal it, the Assembly would not fail to point it out.

On the other hand M. Fernandes felt that he was bound by the traditions of his country scrupulously respected in the plan of $M$. Bevilaqua, and in this respect he felt all the more at his ease because Brazil, being a member both of the Council and of the Assembly of the League of Nations, found itself precisely to be one of those states which would benefit by the said inequality.

In conclusion, M. Fernandes suggested that if, as he supposed, the intervention of the Council had no other object than to ensure to the Great Powers an effective control over the organisation of the Court, the same result might be reached by vesting the election in the Assembly alone, by insisting on a sufficiently large majority, a majority of two-thirds or of three-fourths, for example. If it is borne in mind that the next Assembly will have 43 members, 10 of which represent the Great Powers including the 5 British Dominions, it will be observed that the desired result may very easily be reached by demanding a given majority.

Except for this important reservation, which requires an amendment, M. Fernandes supported the Root Phillimore plan. 